\title{
Preliminary Application of Micro-Course in Distance Education
}

\author{
Tianxiang Hou, Xuerong Gou, and Yingfang Gao
}

\begin{abstract}
In our attempt to shed some light on the potential role that micro- courses may play in the distance education, we have tried to from four aspects to focus on the feasibility of application of micro- courses in distance education. Firstly, summarize -the concepts and definitions of Micro-course. Secondly, examples -make a brief description and analysis of the situation of micro-course, such as research papers, the existing micro-course resources as well as the classification. Thirdly, analysis-analyze the feasibility of application of microcourses in distance education, we concluded that the two can complement each other, make up for their shortcomings. Finally, summary-we put forward micro-course design principles in distance education and extract the micro- course design model.
\end{abstract}

Index Terms-Micro-course, distance education, on-line course, design.

\section{INTRODUCTION}

With the information technology and communication technology development, the update rate of knowledge and technology is faster and faster. "Micro" has become synonymous of the times, micro-blogging, micro-channel, micro-film, micro- fiction... these "micro" things meet the demand for fast-paced life. As the need on mobile learning, ubiquitous learning increases, following the micro-study, the rapid rise of micro programs to meet people's curiosity. As the old saying goes, Avenue is simple, Great sound is hard to hear. The micro-course as described in the name of the micro and focus, is the essence of knowledge. Same to the concept of TED: cup of coffee, see a great speech, and thus the knowledge was spread.

\section{OVERVIEW}

In 2008 the American college of new Mexico, SAN Juan David Penrose proposed the concept of "micro - section", Chinese scholars translated as "wekecheng", since then opens the micro course of trip to China [1]. Micro-course is happening in the Internet era, the researchers from different perspectives have different understanding on it. David Penrose [2], the Micro-course proposer, pointed out that the knowledge of the course is 60 seconds pulse, based on the

Manuscript received July 18, 2014; revised October 8, 2014. This Project Name: Practice teaching reform and research of further education courses in communication.

Tianxiang Hou and Xuerong Gou are with the Beijing University of Posts and Telecommunications, Beijing, 100876, China (e-mail: houtianxiang12@126.com, xrg@126.com).

Yingfang Gao is with the Shanghai International Studies University, Shanghai, 200080, China (e-mail: ning0yun@yeah.net). constructivism theory, the purpose is to instruct and guide students to active learning. EDUCAUSE magazine [3] regarded micro-course as course which is to display a single, strictly defined theme in the form of video or audio. Chinese scholar, Yuping Li, pointed out that micro-course creates a five minutes of learning mode; Jiahou Li professor put forward the concept of micro-course as micro-course refers to the time in 10 minutes, has a clear teaching goal and short content, shows a small problem in concentrated form.

Based on the research on design of micro-course and the application of distance education, the author suggests that the micro-course is through the form of video or audio to explain a particular key or important concept, according to the different knowledge the time can be different, but not more than 15 minutes. It can be used in online learning, blended learning and face-to-face learning, and also be the leaning feedback based on some learning activities and learning tasks. Micro-course can provide students with "buffet" repository, not only for the preview before the course or middle on the course of studying, but also review after class, can help students understand some key concepts and some knowledge and skills which are too difficult to understand but required to master.

When design micro-course, you have to consider students attention. Wankat [4] pointed out that generally the student's attention range is 10 to 20 minutes, 15 minutes later, the students will need a short rest. Hartley and Davies studies have shown that separating a big speech into small pieces can maintain the participation of the students. So, micro-course of the condensed type, with the characteristics of short, can put the students' attention on a certain topic, decreases the chance of students distracted. Through micro-course students can not only learn no matter where and when they are, but also set their own learning tone, which really reflects the thought of learner centered.

From the psychological analysis, attention is the ability of orientation and concentration to a certain object, when people pay attention to an object, the cerebral cortex and the corresponding area can form an advantage excited center. Both subjective factors and objective factors can affect attention. Subjective factors mainly include cognitive level, past experience, emotional state, personality traits, etc.; And objective factors involve relatively intense stimulation activities, comparing new things, things change and novelty, et al. Focusing on the new knowledge, students maybe react more quickly and more profound, more durable which of course improves studying efficiency. Studies have shown that the attention of children generally can maintain 10 to 15 minutes, adults may be slightly longer, but considering the influence of subjective and objective factors, micro-course should be controlled in 15 to 20 minutes, if it is too long, 
designer should consider intervention which causes changes to stimulate learning activities.

\section{The Research SituAtion OF MicRo-CourSE}

\section{A. Analysis of Micro-Course Studies}

\section{1) Statistical analysis of literatures}

In this paper, the selected samples from WanFang DATA and the paper volume of China Category (CNKI) database. "Micro-course" as a keyword, to retrieve the two databases, from the January 2012 to June 2014, the relevant contents of the retrieved are hundreds of articles . After removal of reports, notices news papers and repeat selections, the remaining 103 (including 4 papers), the number of samples shown in Table I.

TABLE I: THE ARRANGEMENT OF CHANNELS

\begin{tabular}{llll}
\hline \hline Year & 2012 & 2013 & 2014 \\
\hline number & 12 & 75 & 16 \\
\hline \hline
\end{tabular}

The quantity of Micro-course studies, according to the statistics as shown in Fig. 1, starting from 2012, has linear growth, which means that the attention of academia on course has risen steadily.

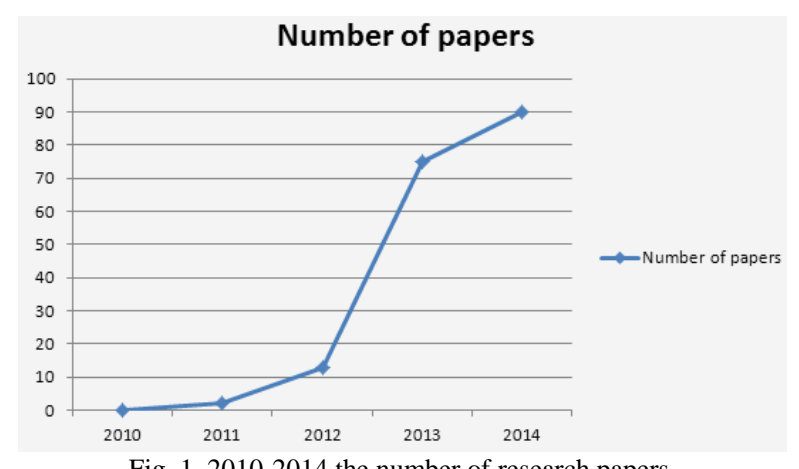

Micro-course researches mainly focus on the analysis of micro-course itself (including the definition and characteristics), design and development of micro-course, the application of micro-courses, as well as the micro-teaching strategy research, etc. Through the analysis of micro-course content, this article mainly from the definition, design and development, application, comprehensive, teaching strategies, teachers` development classifies micro-course research papers, the classification of micro-course content subject as shown in Table II.

TABLE II: THE STATISTICAL ANALYSIS OF MiCRO-COURSE CONTENT

\begin{tabular}{lllll}
\hline \multicolumn{1}{c}{ TABLE II: THE STATISTICAL ANALYSIS OF MICRO-COURSE CONTENT } \\
\hline Subject & 2012 & 2013 & 2014 & Percentage \\
\hline Definition & 5 & 10 & 0 & 14.6 \\
Design & 2 & 28 & 8 & 36.9 \\
Application & 2 & 29 & 7 & 36.9 \\
Teacher & 3 & 3 & 1 & 6.9 \\
development & & 3 & 0 & 2.9 \\
Teaching strategy & 0 & 2 & 0 & 1.9 \\
The others & 0 & 75 & 16 & 100 \\
Total & 12 & & & \\
\hline \hline
\end{tabular}

For micro-course of study in China starts late, microcourse is in the stage of development, at present the course focuses on two aspects of design and development and application. AECT94 definition of education pointed out that the education technology mainly includes five aspects: design, development, utilization, management and evaluation. In accordance with the definition, micro-course of study in China lacks of research on two aspects of management and evaluation. So, the study can continue to broaden, totally involves the aspects of design, development, utilization, management and evaluation. And evaluation plays the promoting role to the development of micro-course.

\section{B. Analysis of Micro-Course Recourses}

The ultimate goal of micro-course development is to sharing of resources. since the birth of micro-courses, scholars, teachers, researchers are trying to do their own micro-course.

\section{1) Micro-course is highly valued by ministry of}

education, the education administrative departments at all levels, micro course game, micro course union carried out one after another

The ministry of education, various provinces and cities education administrative departments at all levels, schools and associations, the leagues are active in the fields of micro-course of the game and the resource construction plan for higher education, basic education, vocational and technical education. In 2013, for example, the ministry of education's nationwide network of university teachers' training center of education and the ministry of education management information center has launched the micro-course game, Zhejiang, Jiangxi, Jiangsu and many other provinces and cities the local administrative department of education has organized their own game and resource construction plan, Education and technology of China association also organized the micro-course competition. In July 2014, micro-course sharing alliance organized the country's second micro-course, which raises the researchers more enthusiasm for micro-course. With the development of the micro-course contest, and the set up of micro-course sharing alliance, Micro-course is highly valued by ministry of education, the education administrative departments at all levels.

\section{2) Micro-course resources are rich}

Micro-course resources are abundant, gradually developing into a series, such as China's micro class network supported by the ministry of education's nationwide network of university teachers' training center of education and the ministry of education management information center, five minutes course network belonged to the national Open University, the micro-course recourses on provincial, city, district (county) education resources network, relevant enterprises institutions course resources, the phoenix micro-course content platform which is constructed by South China Normal University and Hong Kong phoenix media group, and a lot of micro-course recourses which are developed by the education administrative departments at all levels, all kinds of schools at all levels and the relevant enterprises. Table III lists the mature micro-course resources in network.

\section{Categories of Micro-Courses}


Micro-course is now in the researching stage, different scholars classify micro-course from different angles. Depending on making tools, micro-courses are divided into two categories by Yuping Li. One is the "micro-course on class", another is the "micro-course on teacher growth".

\begin{tabular}{|c|c|c|}
\hline NO. & Name & Website \\
\hline 1 & Micro-course of Yanping Li & $\begin{array}{l}\text { http://whliyuping.blog.163.c } \\
\text { om/ }\end{array}$ \\
\hline 2 & Huaqi Business School & $\begin{array}{l}\text { http://www.hq88.com/index. } \\
\text { shtml }\end{array}$ \\
\hline 3 & $\begin{array}{l}\text { 1st national micro- course } \\
\text { contest website }\end{array}$ & $\begin{array}{l}\text { http://jyt.weiba.cn/index.sht } \\
\text { ml }\end{array}$ \\
\hline 4 & $\begin{array}{l}\text { 2ed national micro-course } \\
\text { contest }\end{array}$ & http://www.iweike.org.cn/ \\
\hline 5 & Micro-learning & http://microlearning.com.cn/ \\
\hline \multirow{2}{*}{6} & \multirow{2}{*}{ Ya Er micro-course } & http://mc.erya100.com/index \\
\hline & & CourseShowAction \\
\hline
\end{tabular}

Depending on the teaching content and teaching methods micro-courses are divided into 11 categories by Tiesheng $\mathrm{Hu}$. The categories include taught, quizzes, inspired, discussion, demonstration, laboratory, exercises, performances, independent study, cooperative learning, inquiry learning [5]. Depending on teaching links micro-courses are divided into 6 categories by Jianxin Fan. The categories include new courses bootstrap, understanding, exercises, summary, interactive, practice [6].

In this paper, we select systematic approach to classify the micro-courses. Summarized as four floor classifications, the main purpose is to facilitate the design and development of micro-courses.

Firstly, depending on the way of application, micro-courses are divided into 3 categories: traditional classroom, blended learning and online learning. Secondly, depending on teaching links micro-courses are divided into 3 categories: before class, in class, after class. Thirdly, depending on the teaching content micro-courses are divided into $\mathrm{N}$ categories. Finally, Depending on making tools, micro-courses are divided into $\mathrm{N}$ categories. For example, my micro-course is for online learning, before class, inspired, Screen- recording. Then designers and makers are clearly know how to do in the next.

This paper discusses the various types of micro-courses in the online course.

\section{Feasibility Analysis of Micro-COURSES IN DisTANCE EDUCATION APPLICATIONS}

\section{A. Problems in Micro-Courses}

Through the analysis of the status of micro-course, the following show some problems of micro-courses themselves.

1) Micro-courses too fragmentation, lack of systematic

At present, China is still in the exploration stage, researchers are still study how to design and make a micro-course. Most resources of micro-courses are come from competition, which are too fragmented, unsystematic, their availability is not high.

2) Practice in front theory, micro-courses lack of evaluation criteria
The most serious problems exist in the production of the micro-courses is that the theory and practice is out of touch. The researchers do not produce micro-courses themselves, producers do not study theory. There is no corresponding evaluation indexes for different types of micro-courses, leading to produce a wide variety of micro-courses work.

This paper explores the analysis of feasibility that micro-courses using in distance education. So that the micro-courses can avoid their own problems, at the same time can make up for the problems in online courses.

\section{B. Problems in Online Courses}

Before explore the combination of micro-courses and online courses, this paper makes a compare between and finds the problems of online courses.

\section{1) Poor applicability of network resources}

Most traditional network resources develop in form of units or chapters. So the resource capacity is larger and coarser. Video length is basically in about 45 minutes, size in about NG. Time and capacity of video resources are "excessive", the result lead to bound learners in front of the computer. Longer video resources are easy bring the feeling of pressure and fatigue to learners. Learners are difficult to grasp what they learn. The chance to see the video back is little. For example: if learner wants to see content in 25 minutes, they have to wait for the video buffering, last he finds the content in 25 minutes is not the content he wants. A new buffering is start.

\section{2) Online course insufficient in independent study resources}

Independent learning is a major feature of online education. Learners can through self-study, to achieve the temporal separation of learning activities. Currently online courses in autonomous learning just reflect learners learn by themselves, but not provide a variety of resources to promote their study.

\section{3) Multi-media resources, less teaching activities}

Online courses have a variety of resources: pictures, text, video, animation, but they do not design rich learning activities. We know that online learning include a series of learning activities, the ultimate goal of it is not only concerned with the design and achieve of educational goals, but also concerned with the learning process as well as the ability which learners gain. So on online learning, firstly, teacher should help learners achieve their learning goal by provide rich learning materials, secondly, teacher should learning activities to develop learners' creative thinking, enhance learners' problem-solving skills.

\section{Micro-Courses Used in Online Courses}

Micro-courses originated in cognitive psychology, its theoretical basis are Constructivism Learning Theory and Cognitive Load Theory.

\section{1) Micro-course "micro" feature, make up the deficiencies in the construction of online courses}

Cognitive load theory suggests that cognitive load is due to the completion of learning activities and learning tasks consume cognitive resources caused. Learning micro-courses, short attention span, cognitive resources consumed less attention, cognitive load is low. Micro-courses, avoiding the 
high load, pressure and fatigue, is more in line with human learning cognitive and study habits, and help to improve learning efficiency.

Micro-course dapper features fully consider the time, attention and cognitive load strength of the learners'. In distance education, you can put a $45 \mathrm{~min}$ online course resources for reconstruction, select the key and difficult points, design them into micro-courses. Learners can according to their actual situation, select the precise knowledge they need, enhance the micro-courses usability.

\section{2) Micro-courses provide adequate independent study} resources for distance education

As a product of the Internet era, micro-courses goal is provide resources for learners self-learning.

Firstly, micro-courses can make learners learn knowledge at anytime, anywhere as they want, and liberate the learner from the computer. We know that the biggest feature of distance learners is that they are adult learners, they do not have adequate time to spend 45 minutes or longer to learn the relevant knowledge before a computer. On the contrary, they are more suitable in the subway, the bus station use all the fragmented time they can use to learn the course knowledge.

Secondly, micro-courses as self-learning resources, reducing the learning burden on the learner's. On the other hand, when learners encounter difficulties, they can ask the teacher more targeted, at last a large goal will be achieved.

Finally, micro-courses can be combined with mobile learning. Create a pleasant learning atmosphere for learners by push the knowledge to learners through micro-letters, et al.

\section{3) Micro-courses Increase interactivity to online courses}

After learning a micro-course learners have more time to think about the content of the knowledge behind, Micro-courses help learners to develop critical thinking. On the other hand, teachers can select some micro-courses set the appropriate teaching activities to enhance interaction with students, develop students' creative thinking.

\section{Impact of Distance Education Bring to Micro-Courses}

Distance education and micro-courses bring welfare to the other. Micro- courses combine online courses and achieve win-win.

\section{1) Distance education enhance systemic to micro-courses}

Micro-courses used in distance education, make itself has systematic.

Design micro-courses for a course in traditional classroom is very difficult, and we cannot guarantee its effect. In contrast, in distance education, each course has been carefully designed, curriculum designers have a deep understanding of curriculum design theory, they can accord to chapter, accord to related topics, to design appropriate micro-courses. A series of micro-courses are closely related to the curriculum, so that the micro-course itself has systematically. Designers through knowledge maps, etc. let the learners have a clear understanding of the relationship between the various micro-courses. The purpose this move is to improve the availability and suitability of micro-courses.

2) Completed evaluation criteria, and promote the development of micro-courses
Micro-courses are courses and have courses' Properties. A complete micro-course includes teaching objectives, teaching content, teaching activities, teaching resources, teaching evaluation. Principles and theories of curriculum design are also suitable for micro-courses design.

Now, the development of distance education in China has been approaching maturity, the design of online resources have a mature evaluation system. The Standards of making an online course are equally applicable to the design and production of micro-courses.

\section{3) Micro-courses take full advantage of student support} services, promoting individualized learning

Micro-courses in distance education, can make learners' learning behavior can be controlled. In distance education student can clearly see what he had learned. By recording, learners can check whether they have forgotten, and review timely. By recording, teacher can push content to learners which are more suitable for themselves. For example, if one student has difficulty in understanding the point of some knowledge, teacher can push related micro-courses to him, until he understands the point. In contrast, if a student learning very well, teacher can help him jump some points, and let him learn next micro-course.

\section{Micro-Courses Design Principles in Distance EDUCATION}

\section{A. Complete Curriculum Design Aspects}

Micro-courses have courses' properties, the design should include teaching objectives, teaching content, teaching activities, teaching resources, teaching evaluation.

When you try to design a micro-course in distance education, the first step is that reconstruct the point in chapter or unit; the second step is select key point, difficult point and doubtful point; the last, use the selected points making up micro-course units or topics. To avoid confuse micro-courses relations among each other and avoid students get lost in disordered micro-courses, this paper poses the design model of micro-courses. We can use tree to show the relationship between each knowledge, each leaf node is a micro-course. As shown in Fig. 2, we can see that point $\mathrm{A}$ includes 5 micro-course, namely CGHEF.

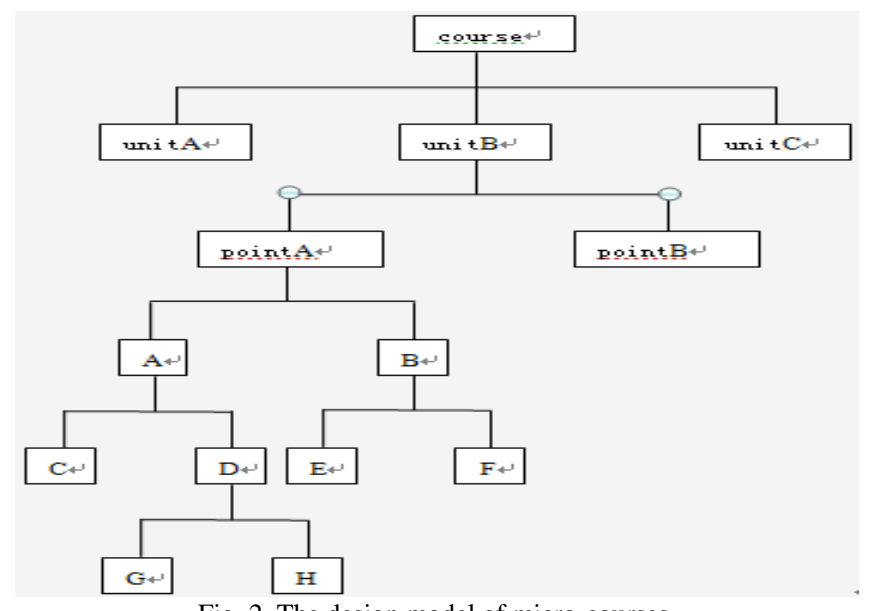

Fig. 2. The design model of micro-courses.

Each micro-course is not just have a micro-video 
component, it includes other teaching activities, like test and activities in class.

\section{B. Note the Design of Learning Environments}

Constructivism Learning Theory is one of theoretical foundations of micro-course. Which emphasizes that learning is construct meaningful knowledge in certain environment. So the design of learning environments is very important.

Micro-course should break the traditional curriculum design perspective, straightforward. To stimulate learners' learning motivation, and guide learners to participate in learning, designers must construct certain situations. Firstly, shaping an image of teacher, making a scene like that teachers are closely. Secondly, to create certain situations, such as to lead students to explore a knowledge point, go to visit one of the characters, etc. Finally, a timely summary and excessive in context.

\section{Note Teaching Interaction Design}

Not only is the presentation of the teaching content, in a way, it is educational philosophy, teaching strategies, teaching mode intrinsic value complex, which reflects the value mainly through the interaction design of micro-course [7].

Chen Li pointed out that distance learning is composed of three different levels of interaction together to complete. Operations including student interaction with the media interface, student interaction with teaching elements (the interaction include student and learning resources, students and teachers, old concepts and new concepts of student).

In the micro-curriculum design, you can add some interaction, such as in the learning process, adding test questions to guide students to operate it, set up that If the learner does not operate, the video will not go forward [8].

\section{SUMMARY AND COMMENTARY}

For micro-courses, someone questioned that: the course is too fragmented, not systematic, and not suitable for complex courses. Only produce the corresponding micro-courses, and put into use, we will know what kind of courses are suitable to micro-courses. The status of application of micro-courses, is the field that researchers yet to be studied.

This paper discusses the application of micro-courses in distance education, In order to solve the questions of micro-courses itself, like lack of systematic and divorced from practice and theory. Similarly, micro-courses bring the gospel to distance education, like improve the utilization of video resources, provide adequate resources for self-learning, increase the number of activities. micro-courses and distance education achieve a win-win. Next, I will study the specific application of micro-courses in distance education.

The application of micro-courses in distance education, may be only a excessive, the ultimate goal of the micro-course is to achieve high-quality resource sharing, will use to online learning .

In the following day, we should strengthen the advantages of micro-courses, using it in online learning, blended learning and face to face teaching. Short and refined features of micro-courses are in accordance with mobile learning, which is fragment and mobile, teacher can push courses to learners as they need. With the advent of $4 \mathrm{G}$ era, micro courses as a major component of mobile learning, o promote the development of mobile learning, by using high-speed upload / download transfer high-quality video images.

\section{REFERENCES}

[1] M. Z. Liu and Z. T. Zhu, "Design analysis and model build of micro-course," China Audio-Visual Education, vol. 323, pp. 127-131, 2013.

[2] B. McCrea, Teaching in One-Minute Snippets, Jan. 20, 2014.

[3] Educause. (2012). 7 Things You Should Know About MICROLECTURES. [Online]. Available: http://www-cdn.educause.edu/ir/library/pdf/ELI7090.pdf.

[4] P. C. Wankat, Allyn, and Bacon, The Effective, Efficient Professor, Boston, 2002.

[5] T. S. Hu and C. Q. Zhan, "Regional practice and enlightenment of primary and secondary quality "micro-class' resource development," China's Education Informationization, 2012.

[6] J. X. Fan, "Design and building architecture of micro-course in distance learning," Journal of Jiangsu Radio \& Television University, vol. 4, 2013.

[7] Y. J Yang and S. Q. Guo, "Interaction design of e-learning learning resources," Modern Distance Education Research, vol. 1, p. 63, 2012.

[8] L. Chen, "Teaching interactive model and teaching interaction level tower of distance learning," Distance Education of China, vol. 5, p. 26, 2004.

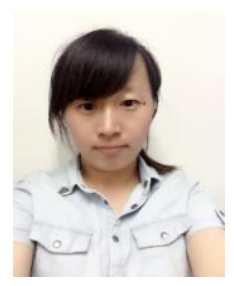

Tianxiang Hou was born in Shandong, on December 12, 1988. She obtaibed her master degree in educational technology from Beijing University of Posts and Telecommunications Beijing, China.

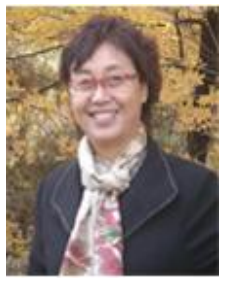

Xuerong Gou was born in Henan, on March 12, 1951. She is a professor and published more than 30 papers. She is interested in design of digital resources.

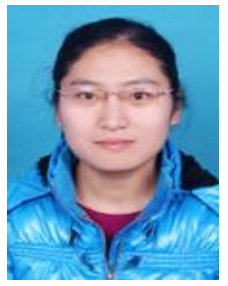

Yingfang Gao was born in Shandong, on November 11, 1989. She is a maser student, majoring in educational technology in Shanghai International Studies University, Shanghai, China. She wrote an article named The Systemtic Design and Develop of Photography Course for the Elderly. 